\section{Pollution Through Traffic and Transport: the Praxis of Cul- tural Pluralism in Parliamentary Technology Assessment ${ }^{1}$}

\author{
by Robert Hoppe, Twente University, and \\ John Grin, University of Amsterdam
}

This paper discusses how "the" transportation problem was structured in traffic and transportation studies by the parliamentary technology assessment (PTA) agencies of Germany, Denmark and the European Union. The focus is on cultural biases in TA methods with regard to the way in which the social problem was defined and translated into research questions (problem structuration), the conclusions drawn from the TA studies, and the recommendations presented. The analysis shows that cultural theory is useful in assessing the degree of pluralism in TA studies. It provides an instrument to probe the assumptions in the viewpoints of experts, lay people, politicians and other actors involved in the technology under scrutiny. It is in this area that cultural theory and political science can fruitfully meet to realize, together, more reflective forms of dealing with cultural pluralism in the praxis of policy analysis.

\section{1}

\section{Introduction}

In the first half of the nineties, car mobility in Western Europe has turned out to be not the unanimous, unambiguous blessing it promised to become in the forties and fifties. To be sure, it has been extremely widely adopted, and it has impacted tremendously on public infrastructures. But at the same time, it is presenting clearly tangible irritations (congestion problems), threats (safety problems) and risks (environmental problems) to a majority of citizens.

Transportation in the 90s represents an unstructured or "wicked" problem (Rittel and Webber 1973; Mason and Mitroff 1980; Hisschemöller and Hoppe 1996) in that both normative dissensus and scientific uncertainty deeply affect the description and explanation of the problematic situation as a gap between some ideal state and present conditions. Un- structured problems easily lend themselves to the politics of meaning (Hoppe 1993) and its rhetoric of naming and framing (Rein and Schön 1993, 1994). To deal effectively with confusing problematic situations, policymakers train the public's attention on aspects and dimensions that, through generative metaphors, can easily be named. Such story-telling simultaneously creates a problem frame, that is a cluster of inextricably intertwined causal and normative beliefs "on which people and institutions draw in order to give meaning, sense, and normative direction to their thinking and action" (Rein and Schön 1994, p. xiii). In mild policy disagreements, frames are shared, or overlap sufficiently for ordinary policy analysis to work. But controversies around messy and unstructurable problems invoke clear cultural biases, or the "contradictory certainties" of conflicting policy frames (Schwarz and Thompson 1990). They bring out the contrasts and limits of a country's political culture, and challenge its institutions and tolerance for cultural pluralism. It is precisely for this reason that unstructured problems are so interesting from the viewpoint of cultural pluralism.

In the following we discuss how "the" transportation problem was structured in traffic and transportation studies by the parliamentary technology assessment (PTA) agencies of Germany (Büro für Technikfolgen-Abschätzung beim Deutschen Bundestag, TAB), Denmark (Teknologi-Naevnet; later on changed to Teknologi-Radet) and the European Union (STOA). Regarding the biases that are allowed or expected in their studies, these agencies, more than others in Europe (Hoppe and Grin 1998), are guided by potentially contradictory considerations. Their interest in institutional survival requires that the data, ideas, and arguments presented in their TA studies be usable for current policy debate, as well as be absolutely impartial. In addition, there is a strong tendency among TA professionals to contribute to "broadening" policy making through including problem aspects and stakeholders that normally get less attention.

We will apply cultural bias theory to accurately uncover how the various biases are represented in the TA studies. Although combining cultural bias theory with literature on the structure of policy belief systems (section 2) 
certainly improved the accuracy of our analysis of the substance of TA reports (section 3), one might argue that, essentially, we are not in need at this point of anything more than cultural theory per se. However, as we will argue in section 2, to understand why the biases are distributed the way they are, we need insights from political science, especially the study of policy change (Sabatier and Jenkins-Smith 1993). We provide a tentative causal model that guides our explanation (in section 4) of the "mix of biases" in the three TA studies.

The analysis is based on a more comprehensive study (Hoppe and Grin 1998), which includes more PTA agencies, and also focuses on cultural biases in TA methods. In addition, the reader will find more detailed descriptions of the three cases presented below, as well as an account of our approach to data collection and analysis.

\section{Theoretical framework}

One of the findings of political science and comparative public policy studies is that policymaking is organized in policy domains or policy subsystems (Parsons 1995, p. 184-192). These are sets of interdependent policy actors from a variety of both public and private organizations, and usually spanning multiple levels of government, who frequently address and process a cluster of related issues (like "traffic and transport"), and share expert knowledge in dealing with them. In their battles on problem definitions and solutions, policy actors advance normative, causal and final (goals-means) claims in more or less coherent and systematic ways. Their convictions can be conceptualized as policy frames (Rein and Schön 1994) and policy belief systems (Sabatier and Jenkins-Smith 1993), or coherently ordered structures of shared values, attitudes and opin- ions (Parsons 1995, p. 374-379). Following Sabatier's layered depiction, deep core beliefs involve fundamental normative and ontological beliefs, which apply to all policy domains without exception. Deep core beliefs constrain, but do not determine policy core beliefs, which are about fundamental problem definitions, policy positions and strategies for achieving core values within a specific policy domain. In their turn, policy core beliefs constrain but do not determine secondary aspect beliefs, which primarily concern preferred instrumental decisions and information searches necessary for implementing the policy strategies chosen at policy core level.

Another finding is that policy elites active in the same policy domain frequently politically mobilize and organize in two or more advocacy coalitions on the basis of sharply different belief systems. Such advocacy coalitions compete to influence governmental agencies to adopt their views in the design and implementation of public policies (Sabatier and Jenkins-Smith 1993). Cultural theory's three publicly active idealtypical biases allow us to derive three idealtypical policy beliefs systems, ordered in the way proposed by Sabatier (see Fig. 1). Since core beliefs apply to all policy domains, we have put here cultural theory's gut convictions concerning the organization of society, as well as the position of mobility therein. Policy core and secondary beliefs correspond to, respectively, dominant problem definitions and preferred policy instruments. The content of the various layers has been based upon previous work on cultural theory and the geographical dimension in public administration (Hoppe 1992), on cultural theory and car mobility (Hendrikse 1994; 1996, p. 1-35, 66-75), and a careful reading of all the TA-studies in our sample. 
Fig. 1: A Cultural Typology of Transport Policy Belief Systems

\begin{tabular}{|c|c|c|c|}
\hline policy core values & $\begin{array}{l}\text { HIERARCHIST/ } \\
\text { ÉTATISTE }\end{array}$ & $\begin{array}{l}\text { INDIVIDUALIST/ } \\
\text { MARKET }\end{array}$ & EGALITARIAN/ PUBLIC \\
\hline $\begin{array}{l}\text { - re. spatial organiza- } \\
\text { tion of society }\end{array}$ & $\begin{array}{l}\text { stable, predictable part- } \\
\text { whole pattern; preference for } \\
\text { vertical relationships; pref- } \\
\text { erence for larger scale }\end{array}$ & $\begin{array}{l}\text { location/distance in hori- } \\
\text { zontal space geared to effi- } \\
\text { cient task performance; } \\
\text { indifference to scale }\end{array}$ & $\begin{array}{l}\text { equally strong }=\text { equal size }=\text { rather } \\
\text { small; preference for smaller scale }\end{array}$ \\
\hline - re. mobility & $\begin{array}{l}\text { orderly and controlled mo- } \\
\text { bility }\end{array}$ & $\begin{array}{l}\text { self determination, individ- } \\
\text { ual mobility, accessibility }\end{array}$ & $\begin{array}{l}\text { equal access by all - residents, } \\
\text { pedestrians, cyclists, motorists, } \\
\text { public transport users - to a liv- } \\
\text { able, sustainable public space }\end{array}$ \\
\hline $\begin{array}{l}\text { dominant } \\
\text { problem } \\
\text { definition }\end{array}$ & $\begin{array}{l}\text { chaos or stagnation; too } \\
\text { little, inefficiently used } \\
\text { capacity; how to keep trans- } \\
\text { port 'stream' in the 'bed' of } \\
\text { existing transport infra- } \\
\text { structure; supply problem } \\
\text { (unless demand stretches } \\
\text { technical possibilities) }\end{array}$ & $\begin{array}{l}\text { shortage of space, passable } \\
\text { roads, useful transport in- } \\
\text { formation; loss of valuable } \\
\text { time and opportunities; } \\
\text { supply problem (demand is } \\
\text { always a given) }\end{array}$ & $\begin{array}{l}\text { excessive demand for (car) mobil- } \\
\text { ity; oversized infrastructure; ero- } \\
\text { sion of public space; deterioration } \\
\text { of environment and residential } \\
\text { areas; demand problem (too much } \\
\text { supply, anyway) }\end{array}$ \\
\hline $\begin{array}{l}\text { preferred policy } \\
\text { instruments }\end{array}$ & regulation $>$ market & market $>$ regulation & $\begin{array}{l}\text { inner conviction }>\text { regulation }> \\
\text { market }\end{array}$ \\
\hline - external costs & $\begin{array}{l}\text { public acceptance of external } \\
\text { transport costs; if unavoid- } \\
\text { able, private imposition of } \\
\text { external transport costs }\end{array}$ & $\begin{array}{l}\text { disregard; if unavoidable, } \\
\text { private acceptance of, or } \\
\text { compensation for external } \\
\text { transport costs }\end{array}$ & $\begin{array}{l}\text { public prevention, or (as second } \\
\text { best alternative) private imposition } \\
\text { of external transport costs }\end{array}$ \\
\hline - supply-oriented & $\begin{array}{l}\text { production of adequate } \\
\text { supply, according to expert } \\
\text { views }\end{array}$ & $\begin{array}{l}\text { increase supply of all possi- } \\
\text { ble transport modes, pref- } \\
\text { erably through public fund- } \\
\text { ing }\end{array}$ & resist all possible supply increases \\
\hline - demand-oriented & $\begin{array}{|lr|}\text { external, administrative } \\
\text { demand regulation through } \\
\text { (physical, technological, } \\
\text { legal) prohibitions, mandates }\end{array}$ & $\begin{array}{l}\text { pay for supply shortages } \\
\text { through market regulation, } \\
\text { i.e. individually focused } \\
\text { pricing systems }\end{array}$ & $\begin{array}{l}\text { manage demand downward } \\
\text { through } \quad \text { education/persuasion } \\
\text { (preferably) or (if need be) through } \\
\text { administrative or market demand } \\
\text { regulation }\end{array}$ \\
\hline - favourite technology & $\begin{array}{l}\text { love of high-tech, large scale } \\
\text { transport } \\
\text { technical fix }\end{array}$ & $\begin{array}{l}\text { love of cars, foremost; tech- } \\
\text { nical fixes }\end{array}$ & $\begin{array}{l}\text { love of low-tech, small scale trans- } \\
\text { port technologies; resist technical } \\
\text { fixes }\end{array}$ \\
\hline
\end{tabular}

This typology will guide us in uncovering the biases in the TA studies below. What we still need is a framework for understanding why different PTA-agencies display different patterns of cultural biases in their TA studies: which factors, causes, or mechanisms contribute to the mobilization of cultural bias of the TA-outputs of the PTA-agencies? In general, the mobilization of cultural bias can be conceptualized as the activation of constrained decision spaces or opportunity structures (cf. Sabatier and Jenkins-Smith 1993, Rockman and Weaver 1993, Hendriks 1996). Policy actors' decisions and actions are either enabled through resources, or limited through con- straints. Resources and constraints impact on decisions and actions through, e.g., the nature of the party system ${ }^{2}$, routinely prescribed decision-making and implementation channels, or media-generated attention structures, political taboos and non-decision areas. Given the cultural predilections or biases of policy actors in a given policy domain, the decision space or opportunity structure obviously affects the probability of e.g. an egalitarian bias to be effectively represented in a TA study; the probability of dominance of one cultural bias over others; or the probability of alliance between biases. 
However, opportunity structures constitute only an intermediate variable, itself affected by two kinds of independent variables (see Fig. 2). External events influence the situational opportunity structure and can be listed as impacts, much like suddenly appearing 'windows of opportunity' (Kingdon) open to policy actors who cleverly exploit them. Culturalinstitutional parameters, on the other hand, have a long term, and potentially much more lasting, inhibiting or facilitating impact on p- portunity structures. They include national political culture, which we conceive as the typical mixture and relative influence of the four idealtypical cultures on the population within the boundaries of a national political territory. Such a cultural mix results from cultural biases' historical sequence of appearance and the dynamics of the state-formation process of a particular country (Eberg 1997, Van Est 1998).

Fig. 2: Linking Institutional-Cultural Variables and external Events to PTAProcesses/Outputs

\section{cultural-institurtional parameters}

1. Socio-econamic
structure
2. Constitutional /
regime structure (esp.
parliament-
cabinetjexecutive-
interest groups-
academic community)
3. Poltical culture;
intellectual traditions;
national policy style

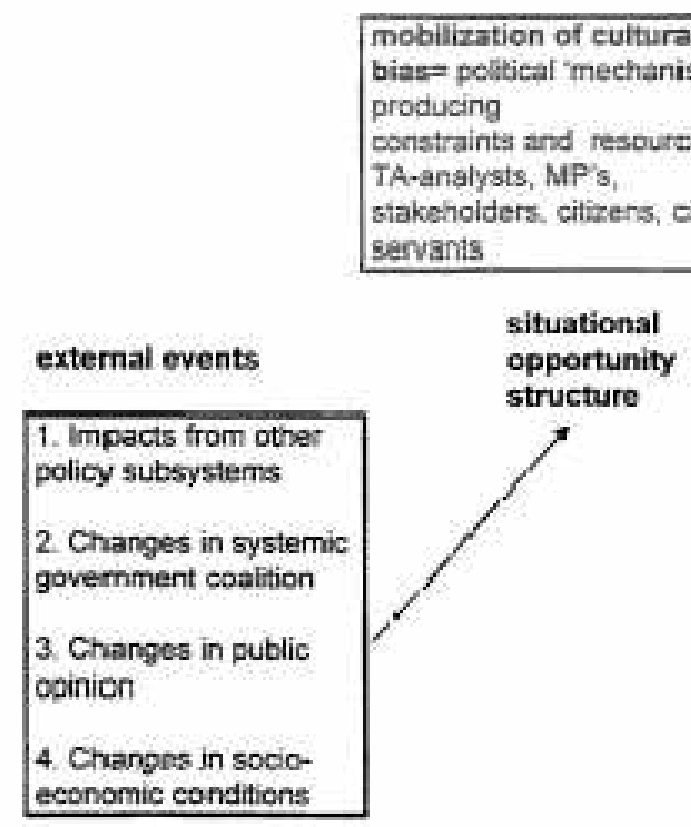

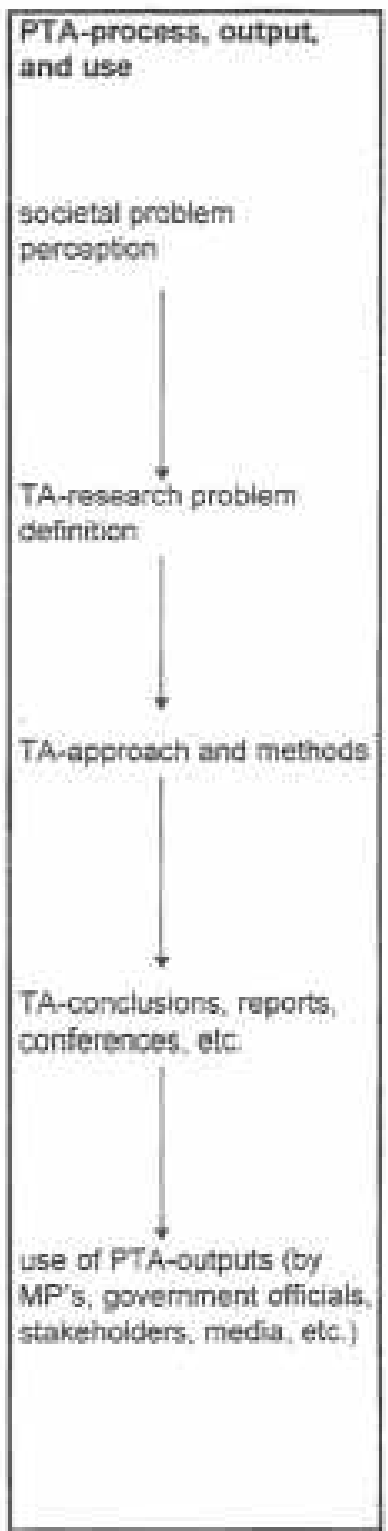




\section{Tales of technology assessment on} transportation

The descriptive format for each case is the same (see the process/output/use box in Fig. 2). First, we look into the (may be iterative) proceeding of the extended translation (cf. Callon 1980) from societal problem into TA-problem, depicted in the process/output/use box in Figure 2. Then we discuss how, after the TAproblem has been processed by applying methods and techniques of research and analysis, the conclusions and recommendations are reached.

\subsection{Teknologi-Naevnet and "The Future of Private (Car) Transport"}

In January 1991 the Danish Ministry of Transport published the Danish Transport Action Plan for Environment and Development. This plan was strongly criticized for refraining from firm measures to adapt traffic plans to sustainability constraints. In October 1991, TN's staff called an expert meeting on its report, "We can't catch up. Sustainability and development on collision course in the traffic sector," a summary and background of all the criticisms against the government's plan. After this expert meeting, TN soon decided to deal with the issue further through its well-known "consensus conference" approach (Agersnap 1992, Grundahl 1995), as it was convinced of both the urgency and the unstructured nature of the societal problem, the incompatibilities between existing traffic policy, and energy and environmental concerns. Moreover, the small expert meeting served to focus on private transport and "green" taxes as promising venues for solutions.

In August 1992 preparations for the consensus conference started in earnest, with a project manager (Ms. Bodil Harder) who had developed a substantive interest in the topic. She became more and more convinced that "the future of traffic" was too broad a theme in the time span of one consensus conference. Therefore, the general question to be addressed was formulated as, How can the Danish parliament influence private car use through transport prices? Four topics were proposed: (1) Will a different taxation system for passenger cars redirect car sales toward more energy efficient, environmentally friendly and safer cars? (2) Given the strong relation between wealth and car use, is it feasible (as a policy goal) to reduce passenger car transport?; (3) Does car mileage depend on gasoline prices?; where is the balance between mobility and negative external effects?; (4) How can a different taxation system for cars be accepted, and will it be effective in making people choose for collective means of transport?

Unusually for a consensus conference, the field of discourse was largely pre-defined. For instance, three scenarios were going to be discussed: (1) More expensive car ownership and car travel; (2) Cheaper ownership, but more expensive car travel; (3) Make people pay for better collective transport; and, finally, compare these three scenarios to (4) a business as usual scenario. Also, criteria were specified for judging the scenarios: traffic safety (in numbers of deaths and accidents), air pollution $\left(\mathrm{CO}_{2}, \mathrm{NO}_{\mathrm{x}}\right)$, energy use, traffic jams, social distribution of mobility, time use, spatial use, barrier and visual effects.

The consensus conference itself followed standard operating procedures as much as possible. The lay panel discarded most of the issues proposed by an expert panel (intelligent roads and cars; specifications for "clean" cars) during a meeting between the two panels. The lay panel did seriously discuss the scenarios, in spite of their own and the facilitator's inclinations to go beyond, or even to disregard them. This was fully due to the conference manager's influence:

"I really wanted them to work with the scenarios. They should write diaries about their transport habits and decisions this week, and think about the consequences if some scenario would be enforced. ... for themselves, but also for those in entirely different traffic positions...."

The results were then compared to the price elasticities incorporated in the quantitative scenario outputs. The conclusion was that the consequences of gasoline price variations were probably bigger than predicted by estimated price elasticities.

After having once more heard experts' and stakeholders' opinions, the lay panel wrote the final document. It starts by laying down traffic 
development policy goals for the Danish government: reduction of energy consumption, pollution, and car accidents; reduction of total mileage of cars; installing a spatial planning system which diminishes the need for car transport; creates more favourable conditions for cyclists and pedestrians; supports and improves public transport modes; and strengthens the mobility of vulnerable groups. (Teknologi Naevnet report 1993/3:11) In order for these goals to be achieved, the lay panel opts for a "medium proposal" which combines several elements from several scenarios: increase or double gasoline prices (over a number of years) to 12 crowns per litre; simultaneously, redesign motor vehicle taxation by weight and for registration so as to reflect pollution effects; and introduce toll roads in the most heavily affected urban areas. The lay panel is concerned, however, that total expenses for an "environmentally friendly" car owner do not increase. It is obvious that the lay panel has embraced the tax/price instrument as a result of the TAexercise. But there are also recommendations for improving public transport, stricter enforcement of stricter emission thresholds, more co-ordinated traffic and physical/regional planning, improved traffic safety, and supportive EU regulation.

\subsection{The TAB Project "Options for reduc- ing the road system burden and for substitution of road traffic by more environmentally friendly traffic sys- tems"}

In March 1993, the Bundestag Committee on Research, Technology and Technology Assessment (hereafter called: the Committee) charged TAB with a study on mobility. The suggestion came especially from its Christiandemocrat (CDU/CSU) members. That the Transportation Committee was not involved, added to the controversial nature of the study. Controversy focused on the issue, especially put on the agenda by the Greens and the social democrats (SPD), whether or not Verkehrsvermeidung (traffic prevention) should be an integral part of the study.

Late 1993, after some preliminary work, TAB submitted a research outline to the Committee. This brief and rather open proposal was accepted. TAB commissioned the German Aerospace Laboratory (DLR) to perform a prestudy. DLR defined the societal problem as the controversy on measures for traffic prevention and displacement. The research questions were (DLR 1994): What technologies and measures are conceivable, and how can these be realized in specific areas? What infrastructure efforts are needed to make people and firms switch to alternative means of transportation, such as train, ship and urban and regional public transport? What combination of measures will give the best results, optimally taking into account economic, ecological and social factors?

These questions were answered by an interdisciplinary team. The findings are organized into a common "pedestal" of necessary measures, to be connected, depending on political preference, to three "pure" or idealtypical strategies. The "pedestal" includes a higher fuel price, stricter enforcement of traffic rules and higher penalties for traffic violations, more attractive public transportation, and technological improvements of cars. The first "pure" strategy concerns pricing policy: road pricing, additional increases of fuel price, differentiating road taxes according to environmental effects of cars, and so on. The underlying conviction is that in transportation the market does not take into account external costs. The second "pure" strategy, regulation, is based on the premise that governmental intervention, aimed at admitting no more traffic than is compatible with an agreeable living environment, is necessary. The third "pure" strategy encourages Umdenken (mindshift) by the public through increasing the weight of environmental considerations in transportation decisions and stimulating the use of public transport through lower prices and better service. DLR suggests that the main study should focus on elaborating this scheme, dealing with the following central questions: Which conditions are needed to realize these strategies; which opportunities do they offer, and which effects will they have on reducing the burden on the traffic network and converting to different means of transportation? What would be an optimal mix of these three strategies?

By and large following these recommendations, $\mathrm{TAB}$ wrote a first design for the main study ("TAB-1", hereafter), submitted to the 
Committee in 1994. The societal problem definition was as follows. The traffic system has become an essential part of the social and economic structure of society. Simultaneously there are adverse effects, that are expected to increase with increasing traffic density. Countermeasures are gaining relevance and acceptance. It seems plausible that this approach which somewhat differed from DLR's proposal - was chosen to anticipate the proposal's reception by the committee.

But, although the Committee formally adopted it in September 1994, the proposal drew increasing criticism after the election of the thirteenth Bundestag, in November 1994. The new Committee considered the proposal too complex and too academic, and thus too politikfern. Given these criticisms, TAB decided that it would be better to focus on a single strategy, resting on a politically appropriate mix of each of the three "pure" strategies distinguished in the prestudy. As of January 1995, it hired Günter Halbritter (ITAS) to elaborate this baseline strategy (Ausgangsstrategie) and to co-direct the rest of the project. When the new draft was discussed, on the Committee's insistence, with its sister committee on transportation, the dispute over traffic prevention reemerged.

In the consequent reformulation of the societal problem, traffic prevention was no longer explicitly mentioned, and individual mobility was stressed. Responding to criticism that traffic prevention had now altogether disappeared, $\mathrm{TAB}$ explained that the project still contained solutions that could lead to prevention. The main research questions are listed as: what is the implementability of various measures? what is their effectiveness? and what are their costs and side-effects? Depending on the answers to these questions, the baseline strategy would eventually be amended.

Subsequently, TAB commissioned DLR and the German Institute for Economic Research to do part of the necessary research. Three scenarios were distinguished in order to estimate the responses of target groups. In the first two scenarios, three types of measures are included: electronic road pricing on highways and on selected main roads; cordon pricing in urban agglomerations; and a moderate fuel tax increase. In the third scenario, road pricing is left out and replaced by a "considerable" increase in fuel tax, while cordon pricing is given the form of stronger paid parking measures and access limitations on specific times of the day. At the time of writing, the TAB study was still underway, therefore the final report could not be included in the analysis.

\subsection{STOA and "The Technological City. Ideas and Experiments in Urban Or- ganization of Mobility, Transport, Production and Services" (June 1994)}

The idea for the "Technological City" (TC) project of the Scientific and Technological Options Assessment Project (STOA) of the European Parliament originated from Bruno Speciale. A former Italian Communist, city councilman, and civil servant of the city of Genova, he had later come to represent the Party of European Social Democrats in the European Parliament. The image of numerous motor vehicles clogging and polluting the arteries of Italy's ancient metropolitan centers definitely was on his mind when he proposed the TC project. It is also clear that Speciale served two political career interests simultaneously: he showed he had not forgotten his political roots, and (thereby also) advanced his (successful) bid to become the next term's chair of the EP's Committee for Regional Policy. But it should not be overlooked that the EP's attitude to regional issues was in principle a favourable one (Westermeyer 1994, p. 60).

For Speciale, the problem was one of finding better ways of city government. This should be done by making an inventory of the technological and methodological options that might be potentially employed to upgrade situations of urban degradation and to re-direct the development of European cities in accordance with an environmentally, economically, and socially sustainable model (STOA 1994, p. 1). In this respect, it was also clear from the outset that the STOA project was not about finding definitive and exhaustive solutions. Rather, the STOA study was conceived by Speciale to be a sort of "kick-off" project. These rather modest project goals fit the STOA Panel's procedural and budgetary constraints well. The project was "awarded" a total sum of 75.000 ECU’s (appr. US\$ 90.000). 
In the subsequent tender procedure, EUROS, a Genova-based institute for operations and systems analysis for urban ecotechnology, came out first. It adopted the research method selected by Speciale: making a compilation of technological and administrative experiments being implemented in European cities, to illustrate that the sustainable development model of fighting urban deterioration could work.

In order to collect these "best practice" examples, EUROS relied on its extensive network of 32 "most qualified experts". In a set of papers written on short notice the following research questions were covered: What are the causes of urban unsustainability?, Which new technologies can help decrease demand for mobility?, Which policies can contain motorized private mobility?, Which "clean" transport technologies do exist?, How can the transport system as a whole be redesigned in order to improve sustainability?, Which new ways of living/working and emerging organizational forms of urban service and other non-material production can be observed?, How can we prevent urban pollution and exhaustion of nonrenewable resources?, What does a model for sustainable urban development look like?, and Which are the major obstacles in the sustainable development of urban systems?

The array and sequencing of these questions betray the haste in which EUROS had to work. To the extent that a central message can be distilled from the plethora of suggestions contained in the EUROS study, it is that innovative traffic management, making full use of "clean(er)" transport and mobility technologies, is the key to sustainable urban development (STOA 1994, p. 39). "Econological" modernization for global competitiveness is the major ideological packaging of this message to the EP.

On the basis of this study, EUROS developed some strategic conclusions regarding both policy suggestions for the EP and follow-up proposals for collaborative projects between
European cities. On the basis of the policy debate in the conclusive stages of a workshop on these conclusions, EUROS listed several policy options for consideration of MEP's. The main ones were: imposition of use of clean urban transport technologies (electrical, low emission vehicles) in certain parts of cities; mandatory urban energy production and consumption planning; development of EU environmental standards and certification procedures for production processes, products and urban service systems; mandatory environmental audits for large urban projects; financial support for disseminating telematics and information technologies; and use of market mechanisms to internalize external costs of environmental damage to humans, animals, the ecosystem, and property.

One recommendation, prudentially labelled as "alternative", is to use traffic planning and management systems to contain and possibly decrease (car) mobility. Finally, there were recommendations to foster efforts between European cities to jointly develop standardized indicators, methods, and instruments for urban sustainability auditing, and, generally, to systematically exchange technological and administrative knowledge about developing sustainable urban systems.

\section{Comparing the contents of the TA's}

To compare the TA contents, we operationalize "content" as: (a) the way in which the social problem was defined and translated into research questions (p\&q); and (b) the conclusions drawn from the TA and the recommendations presented (c\&r). We indicate items by $\mathrm{H}$, I and $\mathrm{E}$ when we consider a particular notion to be typically hierarchical, individualist or egalitarian, respectively. Sometimes, we indicate a mix of idealtypical cultures; if, in such instances, a score is put in brackets, it indicates moderate weight only. 
That almost 40 per cent of the cells remains empty should not come as a surprise. First, once core beliefs have been considered in the context of defining the social problem, they normally need not be restated when discussing recommendations to solve that problem (STOA). If restated, this may lead to a different set of assertions. This is what happened in the nates how TA analysts shift from strong to loose couplings in responding to a change in the political landscape through stressing its strictly neutral position and service function. Neutrality translates into not (explicitly) anticipating solutions when constructing the problem.

The single most striking feature in Table 1

Table 1: Cultural biases in the contents of TA studies

\begin{tabular}{|c|c|c|c|c|c|c|c|}
\hline $\begin{array}{l}\text { PBS element / } \\
\text { TA study }\end{array}$ & \begin{tabular}{|l} 
policy core: \\
spatial \\
organization
\end{tabular} & $\begin{array}{l}\text { policy core: } \\
\text { mobility }\end{array}$ & $\begin{array}{l}\text { problem } \\
\text { definition }\end{array}$ & $\begin{array}{l}\text { policy instru- } \\
\text { ments: } \\
\text { external costs }\end{array}$ & $\begin{array}{l}\text { policy instru- } \\
\text { ments: supply } \\
\text { oriented }\end{array}$ & $\begin{array}{l}\text { policy instru- } \\
\text { ments: de- } \\
\text { mand oriented }\end{array}$ & \begin{tabular}{|l} 
favourite \\
technology
\end{tabular} \\
\hline $\begin{array}{l}\text { TAB-1 } \\
\text { p \& q }\end{array}$ & $\mathrm{H}$ & $\mathrm{H}$ & $\mathrm{H}(\mathrm{E})^{5}$ & $H, E^{6}$ & $\mathrm{H}, \mathrm{I}$ & $\mathrm{H}, \mathrm{E}$ & $\mathrm{H}, \mathrm{E}$ \\
\hline$c \& r$ & & $\mathrm{H}$ & $\mathrm{H}(\mathrm{E})^{7}$ & $H, E^{8}$ & H, I. E & $\mathrm{H}, \mathrm{I}, \mathrm{E}$ & $\mathrm{H}, \mathrm{I}, \mathrm{E}$ \\
\hline $\begin{array}{l}\text { TAB-2 } \\
\text { p \& q }\end{array}$ & $\mathrm{H}$ & $\mathrm{H}$ & $\mathrm{H}, \mathrm{I}$ & & & & \\
\hline$c \& r^{9}$ & & & & $\mathrm{H}, \mathrm{E}$ & H, I & $\mathrm{H}, \mathrm{I}, \mathrm{E}$ & $\mathrm{H}, \mathrm{E}$ \\
\hline $\begin{array}{l}\text { TN } \\
\text { p \& } q^{10}\end{array}$ & & $\mathrm{H}$ & $\mathrm{H}, \mathrm{E}$ & $\mathrm{H}, \mathrm{E}$ & & H, I. E & \\
\hline$c \& r$ & H, E & $\mathrm{H}, \mathrm{E}$ & $\mathrm{H}, \mathrm{E}$ & $\mathrm{H}, \mathrm{E}$ & $\mathrm{H}, \mathrm{E}$ & $\mathrm{H}, \mathrm{I}, \mathrm{E}$ & $\mathrm{H}, \mathrm{E}$ \\
\hline $\begin{array}{l}\text { STOA } \\
\text { p \& q }\end{array}$ & E & $\mathrm{H}$ & $\mathrm{H}, \mathrm{E}$ & I & $\mathrm{H}, \mathrm{I}(\mathrm{E})$ & $\mathrm{H}(\mathrm{E})$ & $\mathrm{H}, \mathrm{I}, \mathrm{E}$ \\
\hline$c \& r$ & & & & II & $\mathrm{H}, \mathrm{I}$ & $\mathrm{H}, \mathrm{I}$ & H, E \\
\hline
\end{tabular}

TAB studies; a not so publicly articulated preference for egalitarian core concerning traffic prevention was suddenly replaced by a strong emphasis on mobility rights. In the Danish case the lay panel emphasized egalitarian core values more than the TN staff which prepared the consensus conference.

Second, in some cases more than others, there is coupling of problems and solutions. TAB-2 is a clear case of loose coupling; TAB1 , STOA, and to a lesser extent TN, show strong couplings. It would seem that problemsolution couplings vary with analysts' perceptions of the political environment, influenced by external events (see Fig. 2). Strong couplings occur where TA analysts construct the political environment as either having stable, clear-cut, well known preferences (TN), or unstable, fragmented preferences over the entire political spectrum, so that TA analysts have to "give everybody his due" (TAB-1, STOA). The transition from TAB-1 to TAB-2 illumi- is that, in all cases, the policy cores show strong hierarchical inclinations. The most plausible explanation is that the position of PTA institutes is tied to those of parliaments in the constitutional and governmental structure. Parliaments are the embodiment of the "primacy of politics"; checking an executive branch, but also, somehow, 'steering' the course of societal forces, both in market relationships and purely social and private associations. Moreover, the "primacy of politics" and "steering" analogy clinging to parliaments, sort of prescribe that only options plausibly available to national parliaments and national governments are seriously considered. Thus, tied to parliaments, TA analysts working in PTA agencies are inherently inclined to take a helicopter's view of all relevant technological aspects concerning a transport and traffic issue, and define problems in a balanced way from this "elevated" position. Moreover, being comprehensive and balanced, having a niche for everything, of course, 
is the political strength of the hierarchical point of view, also in a democratic polity and society. To be sure, stressing étatiste preferences regarding the spatial organization of society and mobility is not identical to stressing market- or public-oriented values; but the former does not per se exclude the latter.

In the Danish and the EU case, policy core values on transport and traffic are not strictly hierarchical. In the Danish case national political culture competes with political structure and political expediency in expressing a different value set, especially in the transport policy domain. In Denmark a pragmatic type of egalitarianism permeates society in almost any respect (Borish 1991, Fuglsang 1993). Bridging the gap between rural regions and cities has been a traditionally salient issue in spatial and physical planning. Thus, it is not surprising that TN had to complement étatiste transport preferences with egalitarian ones.

Although "national" political culture, of course, cannot explain STOA's stressing of egalitarian values of spatially organizing society, $E U$ political culture can, reinforced by the political inclinations of its political initiator, Mr. Bruno Speciale. Speciale, as an Italian Eurocommunist-turned-social democrat, belongs to what Wildavsky has labelled the typical West-European creed of socialism: using hierarchy (state bureaucracy) to achieve egalitarian ideals. His egalitarianism was backed up, in the STOA case, by official EU policies to boost regionalism as a political and administrative force in the Community. As an essentially intergovernmental organization, lacking supranational authority, EU cannot but evoke egalitarian principles in justification of its regional policy initiatives - if not as a deep political undercurrent, then at least as important rhetorics. (Shackleton 1991)

Looking at policy instrument preferences in Table 1, some interesting features stand out. First, overall, hierarchic instruments still dominate instrument or technology option choice. This may come as a surprise to those who believe that the neo-liberal reforms sweeping over West-European politics have deeper footprints. However, never throw away old shoes before you have new ones, appears to describe the present situation better. Yet, and second, this is not to say that instrument choice is fully compatible with hierarchic core value and problem definition preferences. Far from it; all three cases (TAB, TN, STOA) show a more or less balanced presence of all three biases in instrument choice ${ }^{3}$.

How can we explain the presence of all three active cultural biases in instrument choice, in spite of (strong) hierarchic core value articulation and (moderate) egalitarian elements in problem definition? STOA is an example of political expediency, rooted in political regime structure and STOA's paradoxical position as serving the European Parliament and being part of the EU bureaucracy at the same time. Its mix of biases at the instrument level reflects an institutional survival strategy to somehow serve, with very limited resources (Westermayer 1994), every party's political desires in a weak parliament where seats are allocated by an election system based on proportional representation.

Political expediency also lies at the heart of TN's selection of individualist pricing instruments to regulate and possibly reduce private car transport. Here the explanatory factor is external events. First, there was an impact from Danish foreign policy, particularly concerning EU policies. At the time, the Danish government was lobbying on the EU level for the ecotax. Second, it is not unlikely that anticipated changes in socio-economic conditions made the Danish government keen on prodding the European Commission in the direction of EU-wide eco-taxation. After all, the Copenhagen region and northern Jutland are bound to become the transport and traffic arteries between Scandinavia and Central and South Europe. The need to finance infrastructure and to regulate swelling transport streams requires the Danish government to expand its "toolkit" of traffic policy instruments. In this interpretation of events, it is also understandable why TN's Board later accused its own conference manager of acting too much as a political instrument; and even told her to find another employer.

Concerning $\mathrm{TAB}$, our first observation is that the methodology of the three idealtypical strategies implied treating the policy-cultural biases on an equal footing. DLR may have proposed this strategy merely from an academic and professional point of view. Aca- 
demically speaking, it is proper procedure and interesting to trace, in a logical way, the policyinstrumental implications of the three "pure" strategies. And professionally, given the intellectual roots of TA in not taking for granted technological fixes, it is only logical to keep alive the egalitarian notion of traffic prevention. Even when these routines fly in the face of political reflexes, while DLR formally gave in, it still tacitly kept alive options which only make sense in connection to traffic prevention. Their professional and academic policycultural bias, of course, was tacitly supported by Greens and Social-Democrats. It is plausible $^{4}$ that PTA institutes, given the professional experience and convictions of their staff, reject technical solutions per se and therefore emphasize the need for prevention and feel comfortable in working with egalitarian instrumental assumptions, even without political support.

\section{Conclusion: Towards culturally re- flexive problem structuring in TA}

We have seen and sought to understand how three parliamentary TA agencies have structured "the" problem of transportation and the environment. As could be expected given PTA agencies' mission and position, all three studies reflect cultural pluralism to at least some extent. We have also seen that the precise nature of the mix depends upon both "stable" factors such as political culture and the analytical routines and normative preferences of TA analysts (all cases), and more dynamic ones, such as the distribution of power between parties represented in parliament (especially $\mathrm{TAB}$ ), and political expediency (all cases). The way in which these factors combined into a way of producing the TA's reflects a largely (the TAB case comprises the most important exceptions) "unconscious" (Schwarz and Thompson 1990, p. 134-135) way of wielding the insights from what we have treated as idealtypical belief systems into a particular closure of the problem.

What can we learn from our analysis about more conscious ways of ensuring cultural pluralism? This question is urgent. There is a pressing need to better understand what forms of procedural rationality are practically available to deal with unstructured or even wicked problems. When it comes to TA, we agree with such authors as Jennings (1987) and Fischer (1990) that more participatory or interactive forms of policy analysis are needed; and indeed, this does imply "rewriting the precepts of policy analysis", as Thompson (1996) suggests.

Our analysis shows that cultural theory is useful in assessing the degree of pluralism in TA studies. Especially when combined with the notion of layered belief systems, it provides us with a rather accurate probe for identifying underlying normative, final and empirical assumptions in the various elements of the analyses.

In a similar way as it has helped us to analyse TA studies, cultural theory could be helpful in actually performing a TA. It provides an instrument to probe the assumptions in the viewpoints of experts, lay people, politicians and other actors involved in the technology under scrutiny. Thus it can help to ensure plurality. Especially combined with the idea of layered belief systems, cultural theory can, in addition, help to reach fruitful ways of structuring the policy problem, which basically amounts to decompose it in such a way, that it becomes solvable through a set of policy measures. That is, one needs to identify appropriately matching couples of problem elements and partial solutions. This, of course, is just the core of what is designated traditionally as political judgement. And although this surely is an "art" (Vickers 1983), it is possible to give guidelines that can help to get from precepts into practical approaches. At the heart of such guidelines for reaching synthesis between a variety of viewpoints is the notion that an actor's policy core and deep core beliefs determine in what ways he or she is - and, for that matter, is not - prepared or eager to adapt problem definitions and judgements on solutions, constituting the secondary aspects of his/her layered belief system. It is in this area that cultural theory and political science can fruitfully meet to realise, together, more reflective forms of dealing with cultural pluralism in the praxis of policy analysis.

In more praxeological terms, some key implications are that

- Policy analysts should develop and more consistently apply guidelines for their praxis so as to adequately deal with the challenges induced by institutional and 
situational conditions. Minimally, analysts should be able to convince practitioners that their ways of problem framing have political relevance. Rules for their praxis should both provide methodological guidance and hint at potentials and pitfalls of policy analysis to deal with contextual factors.

- The other way round, their "clients" and "addressees" should better acknowledge the legitimacy and necessity of professional policy analysts' role in problem structuring. Practitioners, be they public officials or elected politicians, and different from their Bundestag colleagues, should be required not to evaluate analytical problem structuration efforts by their political and ideological reflexes alone; but to judge these efforts with an open mind, a learning attitude, and an appropriate sense of respect for political pluralism.

\section{Footnotes}

1) The article was first published in: Michael Thompson, Gunnar Grendstad and Per Sell (eds.), 1999: Cultural Theory as Political Science. Routledge/ECPR Studies in Political Science, chapter 10 (p. 154-169)

2) E.g., consider the prospects of a Green political party in the British two-party system with a first-past-the-post rule with the German multiparty system with a rule of (constrained) proportional representation.

3) In this respect, two of the other cases discussed in our comprehensive study (the French and the Dutch ones) were different in that instrument choice was fully consistent with hierarchic deep and policy core elements.

4) In our comprehensive study, it is shown that something similar happened in the British case, while our hypothesis is also able to explain some particularities of the French case.

5) Problem definition by $\mathrm{TAB}$ and research questions in the DLR pre-study.

6) Solutions implied in the research questions of the DLR pre-study.

7) Main research question as recommended in the DLR pre-study, and problem definition in the first design as envisaged by TAB.

8) The three "pure" strategies are interpreted as indicators for possible solution types.

9) The baseline strategy as indicating types of recommendations foreseen by $\mathrm{TAB}$.

10) Considered here are TN's social problem definition in the broad sense (from which eco- taxation is a derivative), and topics identified for the consensus conference.

\section{References}

Agersnap, T., 1992: Consensus Conferences for Technology Assessment. In: Technology and Democracy. The use and impact of technology assessment in Europe. Proceedings of the $3^{\text {rd }}$ European Congress on Technology Assessment.

Borish, S.M., 1991: The Land of the Living. The Danish Folk High Schools and Denmark's NonViolent Path to Modernisation. Nevada City: Blue Dolphin Publishing Comp.

Braybrooke, D.; Lindblom, Ch. E., 1963: A Strategy of Decision. New York: Free Press.

Callon, M., 1980: Struggles and negotiations to decide what is problematic and what is not. The socio-logics of translation. In: Knorr, K. et al. (eds.): The social process of scientific investigation. Dordrecht: Reidel: 197-219

Dobbin, F., 1993: What do markets have in common? Toward a fast train policy for the EC. In: Eliassen, S.S.; Eliassen, K.A. (eds.): Making Policy in Europe. The Europeification of National PolicyMaking. London etc.: SAGE Publications: 71-91

Eberg, J., 1997: Waste Policy and Learning. Policy Dynamics of Waste Management and Waste Incineration in the Netherlands and Bavaria. Delft: Eburon.

Fischer, F., 1990: Technocracy and the politics of expertise. Newbury Park: SAGE.

Fuglsang, F., 1994: Technology and new institutions: a comparison of strategic choices and technology studies in the US, Denmark, and Sweden. Copenhagen: Academic Press.

Grin, J.; van de Graaf, H.; Hoppe, R., 1997: Technology Assessment through Interaction. A guide. Den Haag: Rathenau Instituut.

Grundahl, J., 1995: The Danish Consensus Conference Model, p. 31-40. In: Simon Joss and John Durant (1995): Public Participation in Science. The role of consensus conferences in Europe. London: Science Museum.

Hall, P., 1993: Policy Paradigms, Social Learning, and the State: The Case of Economic Policymaking in Britain. Comparative Politics 25 (April): 275-296 Heidenheimer, A.J. et al., 1990: Comparative Public Policy. The Politics of Social Choice in Europe and America. New York: St. Martin's Press.

Hendriks, F., 1996: Beleid, Cultuur en Instituties. Het Verhaal van Twee Steden. Leiden: DSWO Press.

Hisschemöller, M.; Hoppe, R., 1996: Coping with Intractable Controversies: The Case for Problem Structuring in Policy Design and Analysis. Knowledge and Policy 8(4): 40-60. 
Hoogerwerf, A., 1984: Beleid berust op veronderstellingen: de beleidstheorie. Acta Politica, jrg. 19, p. 493-532

Hoppe, R., 1992: Enkele opmerkingen over de bestuursgeografische bijdrage aan een constructivistisch-critische bestuurskunde. H. van den Brink red. Bestuur en Territoir. Opstellen aangeboden aan drs. A. Bours. Amsterdam: Het Spinhuis: 69-81.

Hoppe, R., 1993: Political Judgement and the Policy Cycle. The Case of Ethnicity Policy Arguments in the Netherlands. In: F. Fischer and J. Forester (eds.): The Argumentative Turn in Policy Analysis and Planning. Durham: Duke University Press: 77100

Hoppe, R.; Peterse, A., 1993: Handling Frozen Fire. Political Culture and Risk Management. Boulder: Westview Press.

Hoppe, R.; Grin, J. (eds.), 1995: Special Issue: Interactive Strategies in Technology Assessment. Industrial and Environmental Crisis Quarterly 9(1).

Hoppe, R.; Grin, J., 1998: Traffic goes through the TA machine. A culturalist comparison between approaches and outputs of six parliamentarian technology assessment agencies' traffic and transport studies. In: Norman Vig and Herbert Paschen (eds.): Parliaments and Technology: the Development of Technology Assessment in Europe. New York: SUNY Press.

Jennings, B., 1987: Interpretation and the practice of Policy Analysis, p. 128-152. In: Frank Fischer and John D. Forrester (eds.): Confronting Values in Policy Analysis. The Politics of Criteria. Newbury Park: SAGE.

Jouvenel, B. de, 1963: The Pure Theory of Politics. Cambridge UK: Cambridge University Press.

Lindblom, Ch.E.; Cohen, D.K., 1979: Usable Knowledge. Social Science and Social Problem Solving. New Haven and London: Yale University Press.

Parsons, W., 1995: Public policy. An Introduction to the Theory and Practice of Policy Analysis. Aldershot UK: Edward Elgar.

Rein, M.; Schön, D., 1993: Reframing Policy Discourse. In: F. Fischer and J. Forester (eds.): The Argumentative Turn in Policy Analysis and Planning. Durham: Duke University Press.

Rittel, H.W.J.; Webber, M.H., 1973: Dilemmas in a general theory of planning. Policy Science, 4(2): 155-169.

Sabatier, P.A.; Jenkins-Smith, H.C., 1993: Policy Change and Learning. An Advocacy Coalition Approach. Boulder etc.: Westview Press.

Sabatier, P.A.; Zafonte, M.M., 1994: Are bureaucrats and scientists members of advocacy coalitions? Two models applied to San Francisco Bay/Delta water policy. (unpublished)
Schön, D.A., 1983: The Reflective Practitioner. How Professionals Think in Action. New York: The Free Press.

Schön, D.A.; Rein, M., 1994: Frame Reflection. Towards the Resolution of Intractable Policy Controversies. New York: Basic Books.

Schwarz, M.; Thompson, M., 1990: Divided We Stand. Redefining Politics, Technology, and Social Choice. New York etc.: Harvester Wheatsheaf.

Shackleton, M., 1991: The European Community between three ways of life. Journal of Common Market Studies, 29:6, p. 575-601

Smits, R.; Leyten, J., 1991: Technology Assessment. Waakhond of Speurhond. Zeist: Kerckebosch.

STOA, 1994: The Technological City. Ideas and Experiments in Urban Organisation of Mobility, Transport, Production, and Services. Luxembourg.

Thompson, M. et al., 1990: Cultural Theory. Boulder etc.: Westview Press.

Thompson, M., 1986: Rewriting the precepts of policy analysis. In: M. Thompson and A. Wildavsky: A Cultural Theory of Information Bias in Organizations. Journal of Management Studies 23(3): 273-286.

Teknologi Naevnet, 1993: Report. 1993/3. Bilismens Fremtid. Slutdokument og scenarier fra konsensuskonferencen 11. - 14. Juni pa Chritiansborg. Teknologinaevnet: Copenhagen.

Van de Graaf, H.; Hoppe, R., 1989 ( $2^{\text {nd }}$ edition: 1992): Beleid en politiek. Een inleiding in de beleidskunde en de beleidswetenschap. Muiderberg: Countinho.

Vickers, G., 1983: The Art of Judgement: A Study of Policymaking. London: Chapman and Hall. $2^{\text {nd }}$ edition

Westermayer, 1994: An Evaluation of the Scientific and Technological Options Programme, STOA, Luxemburg (October 1994, PE 164.968), 120 pp.

\section{Contact}

John Grin

University of Amsterdam

Department of Political Science

O.Z. Achterburgwal 237

1012 DL Amsterdam, The Netherlands

Tel.: + 31.20.525 2108/ 3090 (secr.)

Fax: + 31.20.525 2086

e-mail: grin@pscw.uva.nl

Robert Hoppe

Twente University

Faculty of Public Administration

P.O. Box 217

7500 AE Enschede, The Netherlands

Tel.: + 31.53.489 4684 / 1160 (secr.)

Fax: + 31.53.489 4682

e-mail: $\underline{\text { R.Hoppe@ bsk.utwente.nl }}$ 